\title{
The Legal Protection For Foreign Investor In Ecotourism Field In Bali
}

\author{
Simon Nahak, I Nyoman Putu Budiartha \\ Univeritas Warmadewa, Denpasar, Bali, Indonesia
}

\begin{abstract}
This study focuses on how the form of Legal Protection for Foreign Investor in Ecotourism in Bali and how the legal consequences of actions against the law for foreign investors in conducting business in ecotourism in Bali. This study used Normative Juridical method with Empirical Juridical collaboration because normatively there are legal provisions in providing legal protection, because in reality there are some cases that contradict and against the law. The aim of this study is to provide legal protection for Foreign Investors in Ecotourism in Bali. The result show that the form of legal protection is legal protection according to Customary law, Positive Law; Civil Code, Administration, Criminal and the legal consequences of perpetrators of unlawful acts on Foreign Investors' assets in the Ecotourism field are the result of being legally accountable for every person /legal entity that commits unlawful acts that must be punished. Conclusions that foreign investors' business in the ecotourism field are given a form of legal protection in accordance with Bali Customary Law, Written Law, namely Civil Law, State Administration and Criminal Law. Legal consequences caused by perpetrators of unlawful acts are detrimental to foreign investors in the ecotourism sector so that perpetrators must be held accountable for legal actions, it is recommended that crime in any form should be avoided and if it occurs must be addressed both through mediation and through legal eradication.
\end{abstract}

Keywords: Ecotourism; foreign investor; law; legal protection

\section{Introduction}

The State of the Republic of Indonesia was built by the aim to protect the whole nation and all spilled blood and increase public welfare as regulated in paragraph 4 of the opening of the 1945 Constitution of the Republic of Indonesia. In order to realize the State's purpose, government has an authority to provide legal protection for every person and legal entity include investor. Investor is an individual or domestic institution that makes an investment that constitute a source of income and foreign exchange for the region as receiver of foreign investors in ecotourism field in Bali. Based on the State's purpose as stipulated in the opening of the 1945 Constitution of the Republic of Indonesia and Article 27 paragraph (1) of the body of the 1945 Constitution of the Republic of Indonesia, the State is obliged to provide legal protection to all citizens without recognizing and distinguishing between ethnicities, religions, races, groups or groups certain communities without exception, including providing legal 
protection to Foreign Investors in the Ecotourism Industry in Bali, because in the enforcement of the legal system there is the principle of equality before the law, for all citizens who live under the provisions of applicable rule and regulations. Therefore, for every person/legal entity who is a perpetrator or victim conducting investment business activities so as caused loss of assets and or damage of assets, legal protection must be provided indiscriminately, anyone including the element "everyone" or "legal entity" as an actor or victims lost and or damaged assets owned by foreign investors in the field of ecotourism, especially for the assets (natural and human resources) of investors in the jurisdiction of Bali Province, Indonesia.

Ecotourism in principle fulfills all four things namely: Conservation of the environment that has been damaged, lost/extinct, Community empowerment, Place of community's residence can be used as lodging for tourists who visits Bali, Increasing economic resilience in the form of improving the economic community that has been contributed by ecotourism investors who invest in Bali.

Furthermore, view of legal protection can be divided into; unwritten law of legal protection according to local customary law as well as written positive protection (protect of written law) in aspects of Civil law, State Administrative Law, and Criminal law, or other written law that is used as a reference legal protection for the community.

Based on legal reasoning in the form of provisions rule and regulation and description of the researcher's opinion, then researcher argues that the state is obliged to provide legal protection against the perpetrators or victims of damage/loss of assets belonging to Foreign Investors in the Ecotourism field in Bali, although there is a gap between reality and prevailing legal norms because in the constitution regulates the legal protection of the community, but in reality the community is very difficult to get legal protection so that there is an adagium " law sharp downward, blunt upward". The following, there are some previous research related to this issue. First, a research conducted by [1]. The study's findings show that ecotourism development in this region is based on a 'hybrid approach' (the combination of boosterism and economic factors), which have led to an unequal power interrelationships and interactions be- tween the natural environment and human, and host and guest. Evaluating the sustainability of ecotourism, from local people's perspectives, has revealed that ecotourism in the Mazandaran province has failed to be sustainable. Secondly, a research done by [2]. This study refers to developing ecotourism in First World, resource-dependent areas and the results showed that without continual government subsidies, ecotourism operations will only survive where profitable. Ecotourism destinations are not necessarily the isolated, resource-dependent areas where economic diversification programs have been implemented. While popular for traditional out- door recreation activities, the place products/cultural landscapes of the OzarksÕ Buffalo River region and northwestern Pennsylvania and the old-growth of the Pacific Northwest will not necessarily attract visitors for for specialty tours unless they had unique identities to differentiate themselves from competing destinations.

Then lastly, a research carried out by [3]. In this article, it have demonstrated how social movement actors are responding to and filling in for the absence of the state in its regulatory role in the context of the socio-environmental conflict sparked by the Alto Maipo hydroelectric project in central Chile. Despite much social controversy, Alto Maipo has been bolstered by a powerful network of corporations at the nexus of water, energy, and mining interests. The Chilean government has facilitated the passage of the project through both political action and regulatory inaction, reflecting the restructured role of the state under the neoliberal institutional order that was in- stalled during the Pinochet regime. Within this order, social movements actors, as intermediary groups, take on the burden of filling the reg- ulatory void, monitoring companies and demanding that the govern- ment hold them accountable to 
environmental regulations. Regarding to the explanation given above, there are several legal issues were formulated as follows: 1. How are the form of Legal Protection for Foreign Investor in Ecotourism in Bali? 2. How are the legal consequences of actions against the law for foreign investors doing business in ecotourism in Bali?

\section{Method}

The method in this study is collaboration with Juridical Normative and Juridical Empiric research (mix method). The Juridical-normative research method chosen by researchers due to normative legal research intended to examine conflict norms of law, unclear norms of law and emptiness of norms of law (blanco norm of law). According to Peter Mahmud Marzuki, legal expert, the types of research using the Normative approach are: statutory approach, case approach, historical approach, comparative approach, conceptual approach [4].

Besides that, researcher also used the Juridical Empiric method with the characteristic of examining the gap between theory and practice (das sein-das sollen) the gap between law in book and law in action.

In collecting the data in this present study, according to Abdulkadir Muhammad that empirical legal research by collecting data in the form of:

1. Primary Data: Empirical data obtained directly from data sources, so it is not processed by other people. The data sources referred to in empirical legal research are:

1) Research location, namely the environment in which the research is conducted, therefore primary data is often called field data

2) Legal events that occur at the study site

3) Respondents who provide information to researchers

The primary data collection method is done by using several data collection methods, namely:

1) Observation (observation) at the research location or the legal events that are the object of study

2) Interviews conducted with respondents who have been determined key figures (key person)

3) Questionnaire, which has been prepared based on the details of the sub-topics discussed

4) Questionnaire about what researchers want to know [5].

2. Secondary data in the form of primary legal materials, namely: legislation, books in literature and sources of secondary legal materials namely: journals, documents, scientific papers.

Therefore, the data in this study was supported by 3 (three) types of data. They are:

a) Primary Data: this data is sought directly into the data source in the field. The possibility of this data in the form of public reaction or parties who litigate in court, the reaction of the notary officials involved in making authentic deeds and used to conduct embezzlement and then analyzed based on legal facts.

b) Secondary Data: This data that has been found by previous researchers that have been reported in the form of publications. It is sourced from polymeric legal materials, namely literature, court decisions, related regulations, mass media news, journals, web and so forth. 
c) Tertiary Data: this data used as information or to clarify if there are primary and secondary data in the form of primary and secondary legal material that is biased in meaning. This data is sourced from dictionaries, encyclopedias and so on.

As stated in its title, this research was conducted in Bali because based on researcher's observation they are some foreign investors doing ecotourism business.

\section{Results And Discussion}

\subsection{Form of legal protection for foreign investors in the ecotourism field in Bali}

The general legal protection, explained by researcher in the narrow and broad sense. Legal protection in the narrow sense is something that is given to legal subjects in the form of legal instruments, both preemptive, preventive and repressive, and in the written form positive or unwritten laws are formed in the form of habit/custom. In other words, legal protection can be interpreted as a description that narrated from the function of law to regulate public order (law in order), namely finding and creating peace for all human interests that exist in society so as created harmony and balance in people's lives. While legal protection in the broadest sense is not only given to all living creatures but all of God's creations, both living and dead, moving, not moving, tangible, intangible, visible and invisible (In Balinese: skala niskala, Tetun, Timor: Ha're, la ha're) and utilized in the context of harmonization a fair and peaceful life, happy born physically.

The legal protection for assets that controlled and owned by Foreign Investors in the Ecotourism field in Bali is a form of legal certainty guarantee for human resources which includes individual/legal entity who conducted daily activities regarding their business specifically in the Ecotourism sector. Natural Resources, in the form of: flat land, rice fields, mountains, hills, rivers, fresh water, beaches, sea, Subak with rice fields, Aungan which form as waterways made in 1939 in the era of empire contained historical value, green love, a place rafting, natural scenery. However, the researcher examined that there was a gap between norms and the reality that occurs in Bali because juridical normatively the state is obliged to provide protection to ensure the certainty of the rights and obligations of citizens as investors both domestic, foreign investors, individuals and institutions to invest in Ecotourism, but in fact some provisions are not implemented seriously by the government or law enforcement officials. In addition, Investors are the most important indicators or parties who play a role in capital market activities. Foreign Investors in the Ecotourism sector are foreign entrepreneurs who invest their capital in Bali especially in ecotourism and tourism environmental services both in the fields of Hospitality, Property, Restaurants, travel agents, and so forth.

As recorded by the BKPM (Investment Coordinating Board) the total investment realization from foreign investors in Indonesia in the January-September 2018 period reaching Rp 535.4 trillion, still dominated by Singaporean Foreign Investors reaching US \$ 6.7 billion or $30.6 \%$ equivalent in RI at 4,381 projects, Japan, $17.4 \%$ of US $\$ 3.8$ billion in 2,731 projects, China $8.2 \%$ of US \$ 1.8 billion of 1,265 projects, Hong Kong $7.3 \%$ of US $\$ 1.6$ billion for 1000 projects, South Korea $6.4 \%$ of US \$ 1.4 Billion with 2,160 projects, Malaysia 1,132 projects valued at US \$ 1.18 billion, USA 512 projects valued at US \$ 1 billion, British Virgin Island 749 projects valued at US \$ 786 million, the Netherlands 724 Projects valued at US \$ 776 million and Australia 532 projects valued at US \$ 344 million. 
Thereby, the form of legal protection provided to the community in the form of legislation that is used as the basis for the basic rules to provide legal protection for foreign investors in the field of ecotourism in Bali, the provisions governing legal protection are as follows:

1. The form of civil law protection is regulated in the Civil Code

2. The form of Administrative Law Protection is regulated in the Law of the Republic of Indonesia Number 9 of 2004 as amendment to the Law of the Republic of Indonesia No. 5 of 1986 concerning State Administrative Court, Law of the Republic of Indonesia No. 51 of 2009 concerning the Second Amendment to the Law of the Republic of Indonesia No. 5 of 1986

3. The forms of Protection in Criminal Law such as criminal acts regarding politeness as regulated and threatened in the Criminal Law Act (KUHP), Law of the Republic of Indonesia Number 8 of 1981 concerning the Criminal Procedure Code (KUHAP), Law of the Republic of Indonesia Number 13 of 2006 concerning Protection of Witnesses and Victims, Law of the Republic of Indonesia Number 39 of 1999 concerning Human Rights, Law No. 32 of 2009 concerning Environmental Protection and Management (PPLH), Law No. 5 of 1960 concerning Basic Regulations on Agrarian Principles is often abbreviated as Basic Agrarian Law, Law No. 13 of 2003 concerning Manpower, Law No. 10 of 2009 concerning Tourism, Law No. 11 of 2010 concerning Cultural Heritage.

With respect to several foreign investment from various countries related to investment in ecotourism, several provisions that explicitly regulate the protection of Human Resources for Foreign Investors and the legal protection of Natural Resources that are the place of business of foreign investors related to Ecotourism in Bali, must be legally protected, because in reality there are still crimes in the form of politeness to foreign citizens, environmental crimes such as environmental pollution (trash everywhere), disposing of waste, seizing land rights, damaging tourist areas, stealing cultural heritage objects and nature reserves.

The form of legal protection provided is a form of customary legal protection that is guaranteed legal certainty in accordance with the law that lives in the community in the form of unwritten local customary law. The concept/theory of law used is the theory of civil law protection according to Mochamad Isnaeni in the form of internal legal protection that is, in forming an agreement, the parties can create their own legal protection what they want according to the agreement. External legal protection explains the protection that comes from the legislation [6]. By law, the State Administration Concept/Theory of Legal Protection according to Philip M. Hadjon writes that "with the government's actions as a central point associated with legal protection for the people, two types of legal protection are preventive and repressive legal protection. In the preventive legal protection, the people are given the opportunity to submit an objection (inspraak: public participation) or opinion before a government decision gets a definitive form. Thus preventive legal protection aims to prevent disputes. On the other hand, repressive legal protection aims to resolve disputes. Preventive legal protection means a great deal of government action based on freedom of action because with preventive legal protection the government is driven to be careful in making discretionary decisions. Thus, the handling of legal protection for the people by the general court in Indonesia is included in the category of repressive legal protection, as is the case with administrative justice, and the only function of administrative justice is the "judicial" function (justitiele functie judicial function) according to [7].

According to Simon Nahak about the concept of Criminal law protection stated that "legal protection is a guarantee of legal certainty of the rights and obligations of witnesses, victims and perpetrators of a general criminal act or a special criminal act, non-penal in the form of penal mediation which always maintains a harmonious relationship between the perpetrator 
and the victim and the perpetrator's family and the victim's family. Preemptive, and Preventive, namely handling crime outside the judicial process. In the form of penal repressive measures, namely the application of criminal law through the judicial process.

Based on the theory and concept of legal protection with reference to the provisions of the applicable laws and regulations, the form of legal protection for citizens who live anywhere, including citizens who make investments as Foreign Investors related to the field of Ecotourism in Bali, Indonesia is through a form of legal protection based on the law unwritten or customary law and Positive law in the form of a form of civil law protection that is a form of legal protection in and out, a form of administrative law protection that is a form of Preventive and Repressive legal protection and a form of criminal law protection through mediation of penal/non-penal (judicial process outside the court in the form of mediation of penalties: consensus agreement) and penalties: actions in the form of a series of criminal acts, criminal errors/responsibilities and sanctions as well as a criminal system through the criminal justice process.

\subsection{Legal consequences of misuse of assets/tourist attractions for foreign ecotourism investors in Bali}

The legal effect is actually an act that is immediately conducted in conjunction with the development of rights and obligations as stipulated in the provisions of the legislation or agreement, both written and unwritten and binds the parties to comply, especially the agreement so that there is no misuse of assets/tourist objects owned by foreign investors ecotourism in Bali. Simon Nahak writes "Legal consequences are all consequences that occur from all legal actions carried out by legal subjects to legal objects or other consequences caused by certain events by the law in question have been determined or considered as legal consequences". Every act that intentionally or unintentionally violates the law will result in legal consequences for persons or other parties who suffer losses resulting in deviations between the rights and obligations of every person or every legal entity.

Empirical level, if the rule of law based on its content is seen as valuable in evaluative validity of the rule of law. In determining evaluative behavior, it can be approached empirically and by way of conversion. Hans Kelsen gives an understanding of the validity and effectiveness of the law, both of which cannot be separated because the level of the law as a whole, and also the legal norms of individuals lose their validity when they no longer apply, and that there is a relationship between legal norms and physical reality, the law appears as a "basis" sein-sollen ", namely sociological reality (social behavior that actually occurs in the reality of real society which refers to normative necessity (rules) because positive legal norms that can be enforced must be created / formed with actions in reality). The second view is that legal norms are considered valid, although people have not known previously.

The legislation that formed should achieve four objectives; to provide a living (to provide subsistence); to provide abundant income (to provide abundance); to provide protection (to provide security); to achieve equality (to attain equity) because a law that gives a lot of happiness to the largest part of the community will be assessed as a good law.

The description emphasized that for every person or legal entity as a perpetrator, violators of the misuse of assets in the form of human and natural resources that have been agreed according to law by Foreign Investors in Ecotourism in Bali, Indonesia must be dealt with firmly both according to the unwritten or written law, both according to customary law and national positive law prevailing and bind citizens to comply with these provisions. 


\section{Conclusion}

The conclusion of the research finding, firstly, Form of Legal Protection for Foreign Investors in the Ecotourism Sector in Bali is a form of legal protection for assets / tourist objects or legal protection for any activities carried out either on Human Resources or Natural Resources through unwritten legal protection according to Customary law and legal protection written according to civil law inward and outward, administrative law in the form of Preventive and Repressive legal protection and Criminal law protection guarantees legal certainty of the rights and obligations of witnesses, victims and perpetrators of a general or special crime, in non-penal terms in the form of mediation always maintain a relationship between the perpetrator and the victim's family and the perpetrator's family with the victim's family. Preemptive, and Preventive, namely handling crime outside the judicial process. In the form of penal repressive measures, namely the application of criminal law through the judicial process. The, secondly, Legal consequences for misuse of Investment Assets owned by Foreign Investors in Ecotourism in Bali, Indonesia are all consequences that occur from all legal actions carried out by legal subjects to legal objects or other consequences caused by certain events by the relevant law have been determined or considered as a result of the law.

\section{References}

[1] H. M. Mosammam, M. Sarrafi, J. T. Nia, and S. Heidari, "Typology of the ecotourism development approach and an evaluation from the sustainability view: The case of Mazandaran Province, Iran," Tour. Manag. Perspect., vol. 18, pp. 168-178, 2016.

[2] D. Che, "Developing ecotourism in First World, resource-dependent areas," Geoforum, vol. 37, no. 2, pp. 212-226, 2006.

[3] S. L. Borgias, "'Subsidizing the State:' The political ecology and legal geography of social movements in Chilean water governance," Geoforum, vol. 95, no. April 2017, pp. 87-101, 2018.

[4] P. M. Marzuki, Penelitian Hukum. Jakarta: Kencana Prenada Media Group, 2009.

[5] A. Muhammad, Hukum dan Penelitian Hukum. Bandung: PT. Citra Aditya Bakti, 2004.

[6] M. Isnaeni, Seberkas Diaroma Hukum Kontrak. Surabaya: PT. Revka Petra Media, 2017.

[7] P. M. Hadjon, Edisi Khusus Perlindungan Hukum Bagi Rakyat Indonesia Sebuah Studi tentang prinsip-prinsipnya Penangannya oleh Pengadilan Dalam Lingkungan Peradilan Umum dan Pembentukan Peradilan Administrasi. Surabaya: Peradaban, 2007.

[8] Simon Nahak, Perlindungan Hukum Lingkungan Terhadap Pengembangan Ekowisata, Harian Bisnis Bali, on Wedenesday, 3 June 2019 p.6 column 1-2.

[9] Business-law.binus.ac.id (Browsed on Friday, 5 July 2019).

[10] Danang Sugianto, Home/Berita Ekonomi Bisnis/Detail, Selasa 30 Oktober 2018 21:30 WIB "Ini Dia sepuluh Negara dengan investasi Terbesar di Indonesia, DetikFinance, Browsed on Tuesday, 6 August 2019 at 22.28. http://eournal.uajy.ac.id/7849/3/2MIH01125.pdf (Browsed on Friday, 5 July 2019).

[11] The Constitution of the Republic of Indonesia 1945.

[12] Law Number 1 of 1946 concerning Criminal Law Rule No Law Number 73 of 1958 concerning Stating the Applicability of the Law of the Republic of Indonesia and amending the Criminal Code Act as amended several times, most recently amended by Law Number 4 of 1976 concerning Amendments and Additions to several Articles in the Criminal Code relating to the subsequent expansion of Criminal Law Provisions for Aviation Crimes and Crimes Against Aviation Facilities / Infrastructure and Amendments to the Criminal Code (KUHP) relating to Crimes Against State Security namely Law of the Republic of Indonesia Number 27 of 1999.

[13] Law Number 8 of 1981 concerning the Criminal Procedure Code (KUHAP) Book of the Civil Code. 
[14] Law of the Republic of Indonesia Number 39 of 1999 concerning Human Rights.

[15] Law of the Republic of Indonesia Number 32 of 2009 concerning Environmental Protection and Management (PPLH).

[16] Law Number 5 of 1960 concerning Basic Regulations on Agrarian Principles is abbreviated as UUPA.

[17] Law of the Republic of Indonesia Number 10 of 2009 concerning Tourism.

[18] Law of the Republic of Indonesia Number 5 of 1990 concerning Conservation of Biological Resources and Their Ecosystems. 